\title{
Poliovirus Receptor Antibody
}

National Cancer Institute

\section{Source}

National Cancer Institute. Poliovirus Receptor Antibody. NCI Thesaurus. Code C122772.

Any immunog lobulin that recognizes the poliovirus receptor protein. 